\title{
Steam Reforming of Residual Oils in Fluidized Bed of Calcined Dolomite
}

\author{
Yoshiro Morita*
}

\begin{abstract}
Steam reforming of eight different residual oils in a fluidized bed of calcined dolomite was investigated under atmospheric pressure to produce fuel gas. Sufficient gasification was achieved at $900{ }^{\circ} \mathrm{C}$ under the following reaction conditions: steam to carbon ratio, $2 \sim 9$ by weight and residence time, $0.4 \mathrm{sec}$ or larger. Almost $45^{\circ} \circ$ of the carbon in the oils was reformed to $\mathrm{CO}$ and $\mathrm{CO}_{2}$. The yield of gaseous hydrocarbons such as $\mathrm{CH}_{4}$ and $\mathrm{C}_{2} \mathrm{H}_{4}$ varied from one oil to another, and it correlated well to the content of saturates in the oil. As a result, the maximum gas yield of $91.3 \mathrm{wt}^{\circ}{ }_{0}$ was obtained.

In the production of $\mathrm{CO}$ and $\mathrm{CO}_{2}$, by steam reforming, the carbon deposited on dolomite played an important role. The steam reforming on dolomite was explained in terms of a mechanism, where the carbon accumulated on the active sites served as intermediate.

During gasification, hydrogen sulfide was removed simultaneously by $\mathrm{CaO}$ in dolomite. The concentration of $\mathrm{H}_{2} \mathrm{~S}$ in the product gas was almost independent of the sulfur content of the feed oil and at $900{ }^{\circ} \mathrm{C}$ it was nearly $0.1 \mathrm{rol}^{\circ}{ }_{0}$. It was shown thermodynamically that the concentration of $\mathrm{H}_{2} \mathrm{~S}$ is reduced to its equilibrium value according to the reaction: $\mathrm{H}_{2} \mathrm{~S}+\mathrm{CaO} \rightleftharpoons \mathrm{H}_{2} \mathrm{O}$ + CaS.
\end{abstract}

\section{Introduction}

Considerable rise in prices, problems of crude oil supply and the more demanding requirements of environmental protection have recently given a new incentive and impetus to further research and technical development for more efficient utilization of residual oils and coal, and various gasification processes have been proposed ${ }^{1)}$. Among the processes, the use of dolomite or some other basic materials would be environmentally sound because of their capabilities to desulfurize $\left.\mathrm{H}_{2} \mathrm{~S}^{2}{ }^{2}, 3\right)$. Actually, basic materials have been used as a sorbent to remove sulfur at high temperature in the following two gasification processes. One is the Chemically Active Fluid Bed process (the CAFB process), developed by Esso Research Center of England, to gasify heavy fuel oil in the fluidized bed of lime particles for production of hot, low sulfur fuel gas ${ }^{4}$. The other is the fluidized bed coal gasification process using dolomite, developed by Westinghouse Research Laboratories, which is a system for combined cycle power generation ${ }^{5}$.

Furthermore, dolomite or other basic materials have been suggested ${ }^{(6,7), 15)} \sim 17$ ) as acitve catalysts for gasification of residual oils at high temperatures.

Received September 6, 1977.

* Department of Applied Chemistry, School of Science and Engineering, Waseda University (Nishiokubo, Shinjuku-ku, Tokyo 160)
A typical application of these catalysts for gasification has been made by Toyo Engineering Corporation and Tokvo Gas Company in their THR process, a tubular steam reforming process, using a catalyst based on calcium oxide to produce synthesis gas and fuel gas from crude oil ${ }^{8}$. However, a fundamental understanding of the catalytic behavior of these materials has lagged far behind their industrial applications.

The authors ${ }^{9) .10)}$ have studied steam gasification of residual oils using a fluidized bed of dolomite to produce fuel gas with low sulfur content.

Dolomite was chosen as an effective catalyst and sulfur acceptor with good resistance to attrition. The steam reforming of pure and lower hydrocarbons has also been investigated to elucidate the nature of the carbon deposited on a basic catalyst such as dolomite ${ }^{11)}$. The present paper reviews our research work on catalytic behavior of dolomite and its desulfurization ability for steam reforming of residual oils.

\section{Experimental}

\subsection{Materials}

Table 1 show's the constitution and properties of feed residual oils used in the present work which were supplied by Nippon Oil Co., Ltd. and Toa Nenryo Kogyo K.K.. This table includes the results of fractionation of residual oils carried out according to the scheme ${ }^{12}$ ) illustrated in Fig. 1. 
Table 1 Constitution and Properties of Feed Residual Oils

\begin{tabular}{|c|c|c|c|c|c|c|c|c|c|c|c|}
\hline & \multirow{2}{*}{ Symbol } & \multirow{2}{*}{$\begin{array}{l}\text { Sp. Gr. } \\
(15 / \\
\left.4^{\circ} \mathrm{C}\right)\end{array}$} & \multirow{2}{*}{$\mathrm{C}$} & \multirow{2}{*}{$\underset{(w t \%)}{\mathrm{H}}$} & \multirow[t]{2}{*}{$\mathrm{S}$} & \multirow{2}{*}{$\begin{array}{l}\text { C. C. R. * } \\
\text { (wt } \%)\end{array}$} & \multirow{2}{*}{$\left|\begin{array}{c}\mathrm{H} / \mathrm{C} \\
\text { (atom/ } \\
\text { atom) }\end{array}\right|$} & \multicolumn{4}{|c|}{ Physical Composition (wt \%) } \\
\hline & & & & & & & & Saturates & Aromatics & Resins & Asphaltenes \\
\hline $\begin{array}{c}\text { Minas } \\
\text { topped bottom }\end{array}$ & $\begin{array}{l}\text { Mi. } \\
\text { Top. }\end{array}$ & 0.8875 & 86.4 & 13.2 & 0.14 & 4.52 & 1.83 & 72.8 & 14.7 & 12.0 & 0.5 \\
\hline $\begin{array}{l}\text { Arabian light } \\
\text { topped bottom }\end{array}$ & $\begin{array}{l}\text { A/L } \\
\text { Top. }\end{array}$ & 0.9416 & 83.4 & 11.8 & 2.81 & 7.77 & 1.70 & 54.0 & 30.9 & 10.9 & 4.2 \\
\hline $\begin{array}{l}\text { Iranian heavy } \\
\text { topped bottom }\end{array}$ & $\begin{array}{c}\text { Ir/H } \\
\text { Top. }\end{array}$ & 0.9636 & 85.6 & 11.4 & 2.55 & 10.65 & 1.60 & 47.0 & 31.9 & 17.6 & 3.5 \\
\hline $\begin{array}{c}\text { Minas } \\
\text { vacuum bottom }\end{array}$ & $\begin{array}{l}\text { Mi. } \\
\text { Vac. }\end{array}$ & 0.9454 & 87.2 & 12.1 & 0.28 & 12.88 & 1.66 & 53.3 & 23.0 & 22.8 & 0.9 \\
\hline $\begin{array}{l}\text { Arabian medium } \\
\text { topped bottom }\end{array}$ & $\begin{array}{c}\text { A/M } \\
\text { Top. }\end{array}$ & 0.9508 & 83.4 & 11.9 & 4.25 & 13.00 & 1.71 & 48.4 & 33.7 & 13.8 & 4.1 \\
\hline $\begin{array}{c}\text { Berri } \\
\text { vacuum bottom }\end{array}$ & $\begin{array}{c}\text { Ber. } \\
\text { Vac. }\end{array}$ & 0.9921 & 85.6 & 11.0 & 3.26 & 14.85 & 1.54 & 35.3 & 46.2 & 14.5 & 4.0 \\
\hline $\begin{array}{l}\text { Arabian light } \\
\text { vacuum bottom }\end{array}$ & $\begin{array}{c}\mathrm{A} / \mathrm{L} \\
\text { Vac. }\end{array}$ & 1.0118 & 85.3 & 10.6 & 3.87 & 17.67 & 1.49 & 29.5 & 47.6 & 22.8 & 0.9 \\
\hline $\begin{array}{c}\text { Arabian medium } \\
\text { vacuum bottom }\end{array}$ & $\begin{array}{c}\mathrm{A} / \mathrm{M} \\
\text { Vac. } \\
\end{array}$ & 0.9990 & 84.2 & 10.3 & 5.50 & 18.30 & 1.47 & 30.1 & 47.5 & 17.0 & 5.4 \\
\hline
\end{tabular}

* C. C. R. means Conradson Carbon Residue.

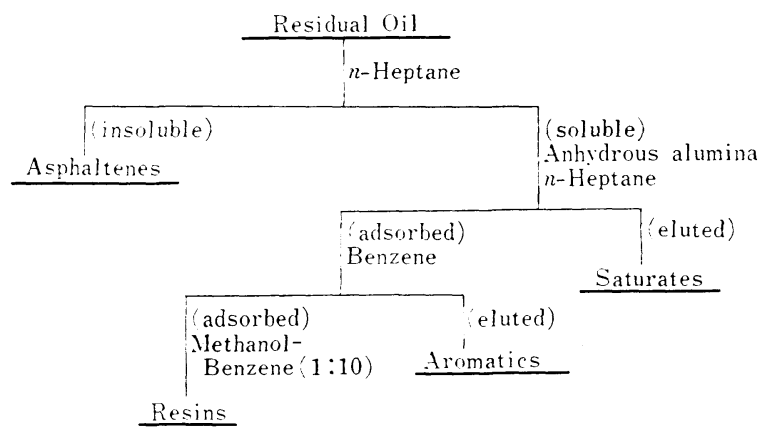

Fig. 1 Schematic Diagram for Fractionation of Residual Oil

Dolomite from Kuzuo, Tochigi Prefecture, was used as catalyst after it was calcined at $950{ }^{\circ} \mathrm{C}$ for $4 \mathrm{hr}$ and crushed (32 65 mesh). The calcination temperature of $950{ }^{\circ} \mathrm{C}$ was found most effective in range $\left(850 \sim 1,270{ }^{\circ} \mathrm{C}\right)$ tested. The composition of calcined dolomite is as follows: $0.75 \mathrm{wt}_{0}^{0 /} \mathrm{SiO}_{2}$, $0.30 w \mathrm{w} \% \mathrm{Al}_{2} \mathrm{O}_{3}, 0.11 \mathrm{wt}_{0}^{\circ} \mathrm{Fe}_{2} \mathrm{O}_{3}, 65.43 \mathrm{wt} \% \mathrm{CaO}$ and $33.41 \mathrm{wt}^{\circ} \% \mathrm{MgO}$.

\subsection{Apparatus and Procedures}

Gasification was carried out over the temperature range of $700 \sim 900{ }^{\circ} \mathrm{C}$ in a fluidized bed reactor under atmospheric pressure. A schematic diagram of the reactor assembly and details of the reactor tube are shown in Figs. 2 and 3, respectively. The reactor tube was of $42 \mathrm{~mm} \phi$ I. D. SUS-27 stainless steel and its bed depth was $400 \mathrm{~mm}$. Stainless beads $(3 \mathrm{~mm} \phi)$ were placed at the conical-bottom of the reactor that served as bed support and gas distributor. Feed oil was admitted from the bottom part of the catalyst bed through an atomizer by use of a microfeeder. From the nozzle of the atomizer, the oil was atomized with steam produced in the steam generator. To prevent the feeding pipe plugging by coking, the atomizer was cooled by

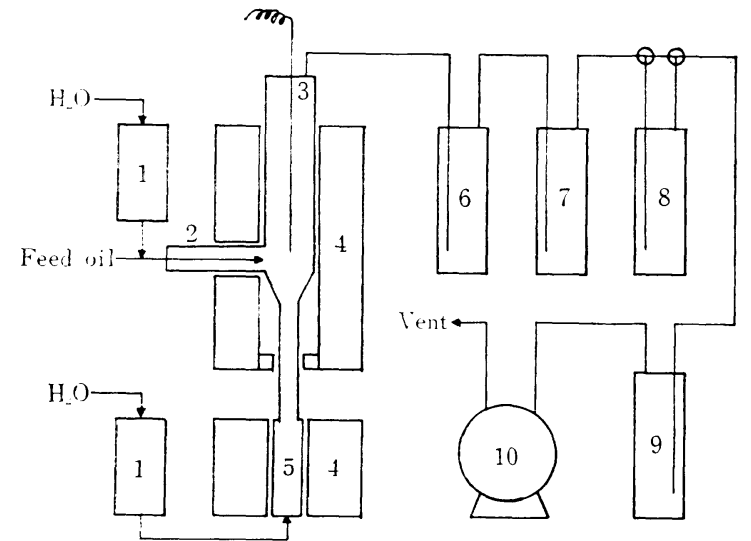

1. Steam generator

6. Ice trap

2. Feed oil atomizer

3. Reactor

4. Electric furnace

5. Steam preheater

7. Mist remover

8. $\mathrm{H}_{2} \mathrm{~S}$ trap

9. $\mathrm{H}_{2} \mathrm{~S}$ remover

10. Wet gas meter

Fig. 2 Schematic Diagram of Reactor Assembly

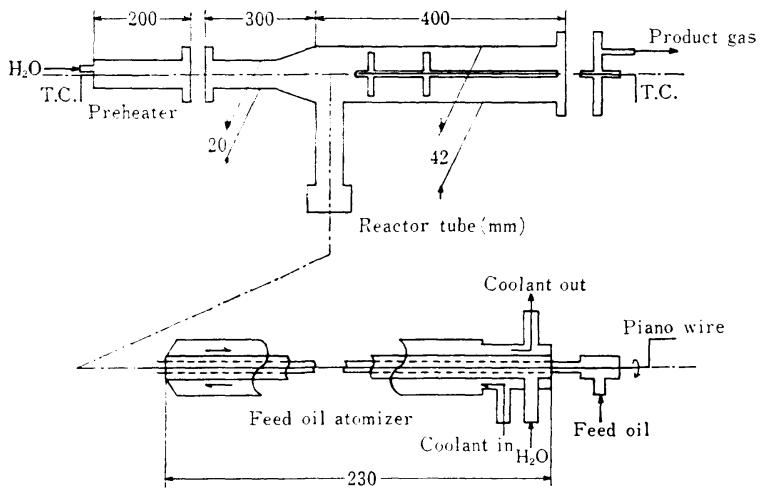

Fig. 3 Details of Reactor

circulating a coolant and periodically rotating a piano wire inserted into the pipe. Steam for fluidization was supperheated at $500{ }^{\circ} \mathrm{C}$ in the preheating section and admitted from the bottom of 
the reactor to the catalyst bed through the stainless beads gas distributor. The catalyst was heated in a steam of nitrogen up to $500{ }^{\circ} \mathrm{C}$, then further heated in a stream of steam up to the desired temperature. After keeping the catalyst at the temperature for $30 \mathrm{~min}$, oil feed was started.

After condensation and removal of liquid products and excess steam with the ice trap, the product gas passed through a solution of ammine complex of zinc to absorb the hydrogen sulfide produced after which the gas volume was measured with a wet gas meter. The content of $\mathrm{H}_{2} \mathrm{~S}$ in the solution was determined by the JIS method K 0108. Gas sampling was done every $40 \mathrm{~min}$. The composition of gas was determined by use of gas chromatography.

Initially, the yield of product gas increased gradually with reaction time and attained after $60 \sim 80$ min, a steady value which was adopted in the following figures and tables. The yield of hydrogen sulfide did not change within $150 \mathrm{~min}$ of reaction time, because the amount of dolomite used was very large in comparison with that of sulfur contained in the feed oil fed.

In these experiments, it was difficult to get an accurate material balance because the yield of liquid products was too small to be determined precisely. As this study was designed primarily to produce fuel gas, discussion will be limited to the results of and based on gasification products.

\section{Results and Discussion}

\subsection{Effect of Reaction Conditions on Gasifica- tion}

To determine reaction conditions for gasification, reaction of Arabian Medium topped bottom residue were investigated under various conditions. Table $\mathbf{2}$ summerizes the results obtained at various reaction temperatures. The total gas yield was determined by summing up the yields of gaseous hydrocarbons, $\mathrm{CO}, \mathrm{CO}_{2}, \mathrm{H}_{2}$ and $\mathrm{H}_{2} \mathrm{~S}$. Here, the yield of hydrogen would mean the amount of hydrogen yielded from the oil. The amount of hydrogen yielded from steam was calculated using the yields of $\mathrm{CO}$ and $\mathrm{CO}_{2}$.

The yield of $\mathrm{CO}$ plus $\mathrm{CO}_{2}$ increased with increasing reaction temperature, and the total gas yield reached about $90 \%$ at $900{ }^{\circ} \mathrm{C}$. The liquid product obtained in the reaction was found to be light oil which contained small quantities of tar and pitch fractions. In this table, the yield of hydrogen obtained at $700{ }^{\circ} \mathrm{C}$ was remarkably high value (8.6 wt $\%$ ). This high value was due to the fact that, under these conditions, a steady state was attained only after a long period of time; as a result, part of
Table 2 Effect of Reaction Temperature

\begin{tabular}{|c|c|c|c|}
\hline Catalyst & \multicolumn{3}{|c|}{ Dolomite } \\
\hline Steam Ratio (g/g) & \multicolumn{3}{|c|}{2.2} \\
\hline Cata. Weight (g) & \multicolumn{3}{|c|}{200} \\
\hline React. Temp. $\left({ }^{\circ} \mathrm{C}\right)$ & 700 & 800 & 900 \\
\hline Feed Rate (g/hr) & 67.8 & 67.8 & 71.7 \\
\hline Residence Time (sec) & 0.75 & 0.75 & 0.46 \\
\hline Gas Vol. (ml/g-feed) & 1,485 & 2,303 & 2,835 \\
\hline \multicolumn{4}{|l|}{ Gas Yield (wt \%) } \\
\hline $\begin{array}{l}\text { Total } \\
\mathrm{Hydrocarbon} \\
\mathrm{CO}+\mathrm{CO}_{2} \\
\mathrm{H}_{2}\end{array}$ & $\begin{array}{r}57.4 \\
41.1 \\
7.7 \\
8.6 \\
\end{array}$ & $\begin{array}{r}74.9 \\
39.3 \\
33.8 \\
1.8 \\
\end{array}$ & $\begin{array}{r}90.3 \\
41.1 \\
47.9 \\
1.3\end{array}$ \\
\hline Carbon Recov. *1) & 49.5 & 75.0 & 91.6 \\
\hline $\mathrm{H}_{2} \mathrm{~S}$ Yield $* 2$ ) & 6.2 & 8.5 & 8.2 \\
\hline Calorific Value $* 3$ ) & 5,521 & 4,049 & 3,874 \\
\hline Thermal Yield $* 4$ ) & 779 & 887 & 1,045 \\
\hline \multicolumn{4}{|l|}{ Gas Composition (vol \%) } \\
\hline $\begin{array}{l}\mathrm{H}_{2} \\
\mathrm{CO} \\
\mathrm{CO}_{2} \\
\mathrm{CH}_{4} \\
\mathrm{C}_{2} \mathrm{H}_{6} \\
\mathrm{C}_{2} \mathrm{H}_{4} \\
\mathrm{C}_{3} \mathrm{H}_{6} \\
\mathrm{C}_{4}+ \\
\mathrm{H}_{2} \mathrm{~S}\end{array}$ & \begin{tabular}{c|}
69.0 \\
1.6 \\
8.1 \\
7.5 \\
2.1 \\
6.4 \\
2.5 \\
2.8 \\
0.12
\end{tabular} & $\begin{array}{c}57.9 \\
11.0 \\
16.4 \\
6.7 \\
0.9 \\
5.9 \\
0.8 \\
0.4 \\
0.11\end{array}$ & $\begin{array}{c}54.6 \\
18.3 \\
13.2 \\
8.4 \\
0.6 \\
4.8 \\
0.1 \\
0.1 \\
0.08\end{array}$ \\
\hline
\end{tabular}

*1) as gas (C mol of gas/C 100moles in feed oil)

*2) $\left(\mathrm{H}_{2} \mathrm{~S} \mathrm{~mol} / \mathrm{S} 100\right.$ moles in feed oil)

*3) $\left(\mathrm{kcal} / \mathrm{Nm}^{3}\right)$

*4) $(\mathrm{JHU} / \mathrm{kcal})$

the hydrogen produced from steam was included in the yield of hydrogen since dolomite absorbed $\mathrm{CO}_{2}$ produced at this temperature. The X-ray examination of dolomite used at $700{ }^{\circ} \mathrm{C}$ showed that $\mathrm{CaO}$ in dolomite changed to $\mathrm{CaCO}_{3}$, whereas $\mathrm{MgO}$ remained unchanged.

Figure 4 shows the results obtained at $900{ }^{\circ} \mathrm{C}$ with various residence times. Here, the residence time $(\theta)$ was calculated according to Eq. (1).

$$
\begin{aligned}
\theta & =\frac{V_{R}-(W / d)}{\left(Q_{1}+Q_{2}\right)(273+t) / 273} \\
V_{R} & : \text { efficient reactor volume }(\mathrm{ml}) \\
W & : \text { catalyst weight }(\mathrm{g}) \\
d & : \text { density of catalyst }(\mathrm{g} / \mathrm{ml}) \\
t & : \text { reaction temperature }\left({ }^{\circ} \mathrm{C}\right) \\
Q_{1} & : \text { volume of steam }(\mathrm{Nml} / \mathrm{sec}) \\
Q_{2} & : \text { volume of product gas }(\mathrm{Nml} / \mathrm{sec})
\end{aligned}
$$

Efficient reactor volume was obtained by multiplying the inner cross section of reactor tube and the depth of the catalyst layer. The depth of the 


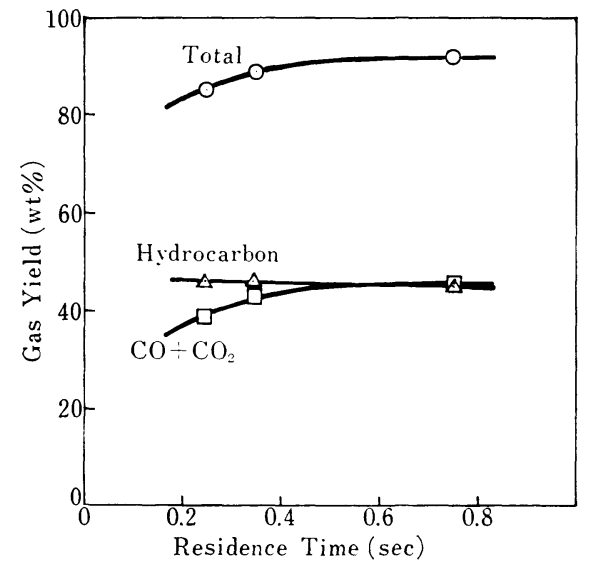

Reaction temperature : $900^{\circ} \mathrm{C}$

Fig. 4 Effect of Residence Time on Gas Yield

catalyst layer was determined by measuring the region of a uniform temperature along the length of the reactor. The residence time was varied mainly by changing the catalyst volume. The yield of $\mathrm{CO}$ plus $\mathrm{CO}_{2}$ increased with increasing residence time, whereas the yield of hydrocarbon remained unchanged.

Effects of the ratio of steam to feed oil (the steam ratio) were examined at $900{ }^{\circ} \mathrm{C}$, where the feed rate of steam was fixed and that of oil varied. Figure 5 shows typical results obtained. The yield of $\mathrm{CO}$ plus $\mathrm{CO}_{2}$ was almost independent of the steam ratio from 3.8 to 7.5. The smaller yield at the steam ratio of 1.9 may partly stem from the reaction that could not carried out in a shorter residence time to obtain good fluidization of dolomite.

\subsection{Gasification of Various Residual Oils}

The reactivity of eight different residual oils was compared at the reaction temperature of $900{ }^{\circ} \mathrm{C}$ with steam ratio of $2.8 \sim 3.0$ and residence time of

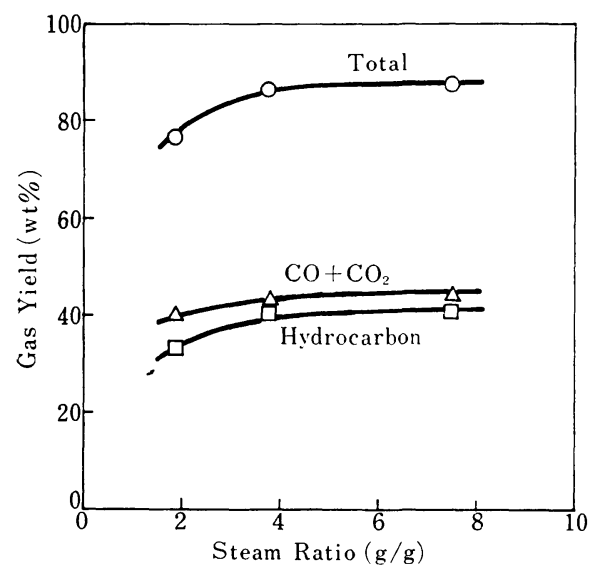

Reaction temperature : $900^{\circ} \mathrm{C}$

Residence time : $0.22 \sim 0.34 \mathrm{sec}$

Fig. 5 Effect of Steam Ratio on Gas Yield

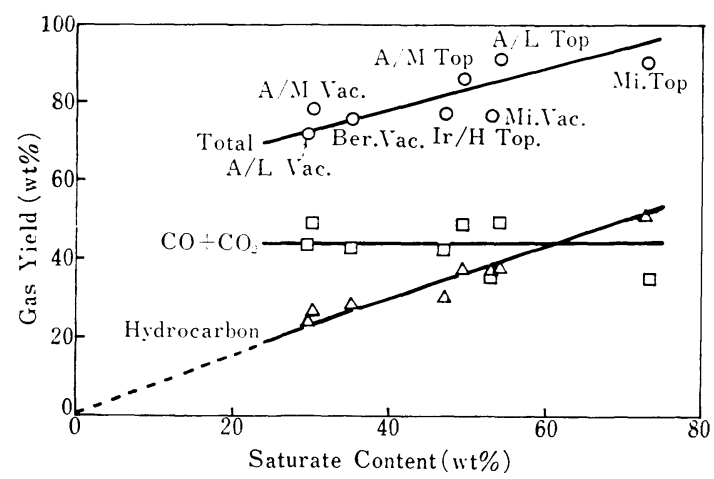

Fig. 6 Relation between Gas Yield and Saturate Content of Feed Oil

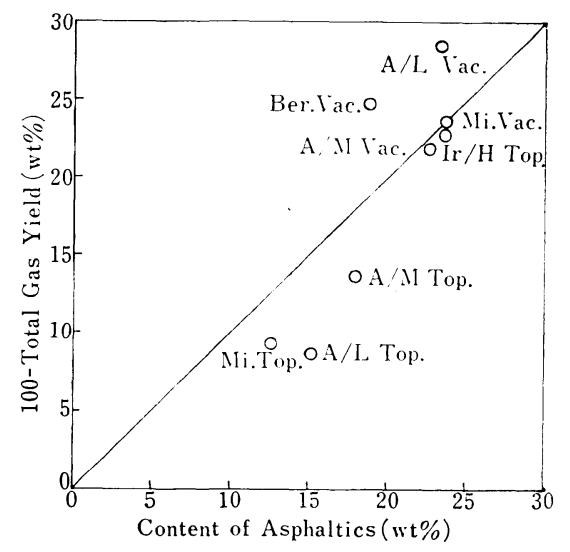

Fig. 7 Relation between Content of Asphaltics and Percent of Feed Oil not Converted into Gaseous Products

$0.4 \sim 0.5 \mathrm{sec}$. These results are shown in Figs. 6 and 7. Although various factors characterizing residual oils have been used, the content of saturates was used here. Figure 6 shows the relation between gas yields and saturate contents in the residual oils. The yield of $\mathrm{CO}$ plus $\mathrm{CO}_{2}$ was almost unchanged from one oil to another, being approximately $45 \%$. On the other hand, the yield of hydrocarbons proportionally increased from $26.5 \%$ to $51.2 \%$ when the saturate content increased from $29.5 \%$ to $72.8 \%$. It seems that gaseous hydrocarbons such as $\mathrm{C}_{2} \mathrm{H}_{4}$ and $\mathrm{CH}_{4}$ were produced mainly through cracking of saturate fraction of the feed oil. The percent of feed oil which was not converted into gaseous products (100-total gas yield) decreased with increase in the content of saturates. As shown in Fig. 7 it was correlated linearly to the content of asphaltics(asphaltenes plus resins). This linear relationship suggests that heavier constituents such as asphaltics hardly were converted into gaseous products during gasification.

\subsection{Garbon Deposition on the Catalyst}

When residual oils were gasified, the product gas yield increased initially and reached a steady level 


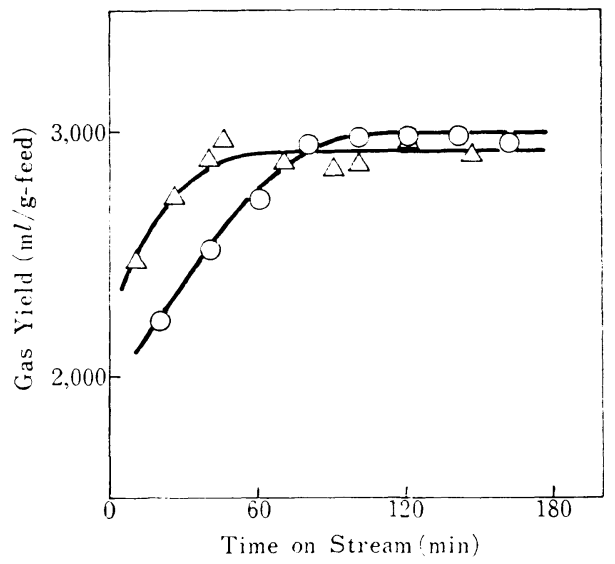

Reaction temperature : $900^{\circ} \mathrm{C}$

Residence time : $0.35 \mathrm{sec}$

Feed rate of steam : $200 \mathrm{~g} / \mathrm{hr}$

Feed rate of oil Catalyst weight

$26.6 \mathrm{~g} / \mathrm{hr} \quad 140 \mathrm{~g}$

$\triangle 72.7 \mathrm{~g} / \mathrm{hr} \quad 240 \mathrm{~g}$

Fig. 8 Variation of Gas Yield with Time

within about $\mathrm{l} \mathrm{hr}$ at $900^{\circ} \mathrm{C}$. A typical time dependent variation of gas yields is shown in Fig. 8. The period required to attain a steady activity varied with the amount of catalyst or feed rate of residual oil. These results suggest that reaction intermediate is accumulated on the catalyst surface in the initial period of reaction and the amount of accumulated intermediate reaches a steady level. This intermediate seems to be the carbon deposited on the active sites of the catalyst. Owing to the deposition of carbon, the color of the catalyst used for $3 \mathrm{hr}$ at $900{ }^{\circ} \mathrm{C}$ turned grayish

The amount of carbon deposited at $900{ }^{\circ} \mathrm{C}$ was not sufficient for its exact determination. The accumulation of carbon at $700^{\circ} \mathrm{C}$ was, however, much more extensive. To determine the relation between the amount of deposited carbon and gasification activity, reaction was carried out at $700^{\circ} \mathrm{C}$. Figure 9 shows the time dependent variation of the amount of deposited carbon and activity in the gasification of vacuum bottom of Berri. The amount of carbon deposited on the catalyst was determined by with drawing the catalyst from the reactor after a certain reaction period and burning off the carbon. The amount of deposited carbon initially increased with reaction period until a maximum is reached then it decreased. The variation in the yield of hydrogen corresponded to the variation in the amount of deposited carbon, indicating that the deposited carbon played an important role probably as an intermediate in steam reforming.

The yield of $\mathrm{CO}_{2}$ increased remarkably after about $60 \mathrm{~min}$ of reaction. At the initial stage of reaction,
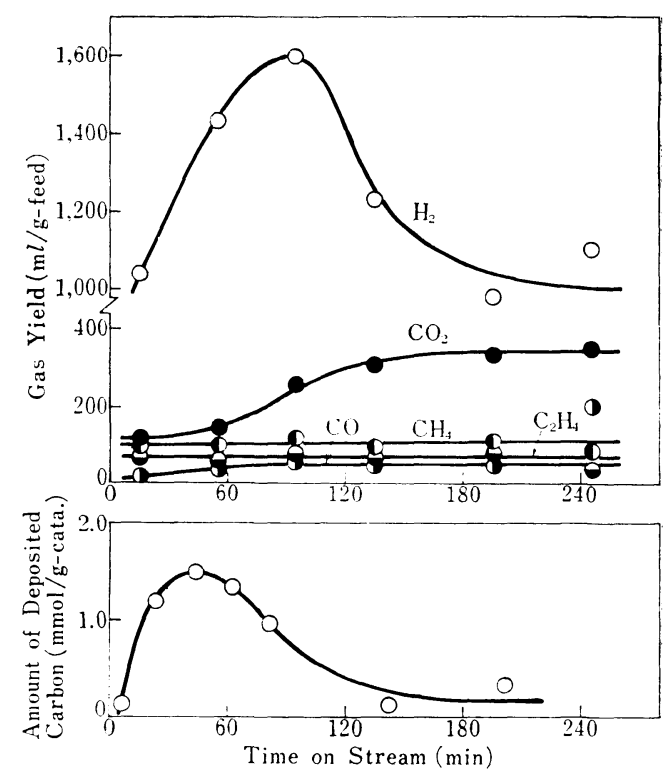

Reaction temperature : $700^{\circ} \mathrm{C}$

Steam ratio $: 2.8(\mathrm{~g} / \mathrm{g})$

Residence time : $0.4 \mathrm{sec}$

Fig. 9 Variation of Gasification Activity and Carbon Deposition with Reaction Time

$\mathrm{CaO}$ absorbed $\mathrm{CO}_{2}$ produced because the temperature was below the decomposition temperature of $\mathrm{CaCO}_{3}\left(825^{\circ} \mathrm{C}\right)$. Therefore, the increase in the vield of $\mathrm{CO}_{2}$ seems to be due to the saturation of absorption of $\mathrm{CO}_{2}$. After saturation, both carbon deposition and hydrogen production decreased. Thus, CaO loses its ability not only to deposit carbon but also to catalyze gasification reactions when it absorbs $\mathrm{CO}_{2}$.

\subsection{Nature of Deposited Carbon}

To elucidate the nature of deposited carbon, this study was supplemented with the investigation of steam reforming of pure and lower hydrocarbons on some basic catalysts such as calcium oxide in a conventional flow system.

Table 3 shows the activity of various catalysts and the reactivity of carbon deposited on them. The catalytic activity was expressed by the space

Table 3 Comparison between Rate of Deposited CarbonSteam Reaction and Catalytic Activity of Various Catalysts for Steam Reforming at $900^{\circ} \mathrm{C}$

\begin{tabular}{l|c|c}
\hline Catalỵst & $\begin{array}{c}r^{*} \\
(\mathrm{mmol} / \mathrm{g} \cdot \mathrm{hr})\end{array}$ & $\begin{array}{c}\text { Space Time Yield } \\
(\mathrm{mmol} / \mathrm{g} \cdot \mathrm{hr})\end{array}$ \\
\hline Dolomite & 14.2 & 15.3 \\
Calcium Oxide & 16.9 & 14.8 \\
Magnesium Oxide & 13.4 & 12.8 \\
Active Alumina & 5.3 & 5.0 \\
$\alpha$-Alumina & 2.6 & 2.8 \\
Silica Gel & 0.9 & 0.6 \\
\hline
\end{tabular}

* The rate of reaction between steam and carbon deposited from $n$-hexane in the absence of steam. 
time yield which was calculated by multiplying the fractional conversion of $n$-hexane to $\mathrm{CO}$ plus $\mathrm{CO}_{2}$ and space velocity: The rate of reaction between deposited carbon and steam $(\mathbf{r})$ was determined from the rates of evolution of $\mathrm{CO}, \mathrm{CO}_{2}$ and $\mathrm{CH}_{4}$ when only steam was admitted to carbon deposited from $n$-hexane onto the catalyst. Moreover, the following relationship was found among the quantities of $\mathrm{H}_{2}, \mathrm{CO}, \mathrm{CO}_{2}$ and $\mathrm{CH}_{4}$ produced in the deposited carbon-steam reaction.

$$
\left[\mathrm{H}_{2}\right]=[\mathrm{CO}]+2\left[\mathrm{CO}_{2}\right]-2\left[\mathrm{CH}_{4}\right]
$$

This relationship means that hydrogen is produced according to the reactions (1) and (2).

$$
\begin{aligned}
& \mathrm{H}_{2} \mathrm{O}+\mathrm{C} \rightarrow \mathrm{CO}+\mathrm{H}_{2} \\
& 2 \mathrm{H}_{2} \mathrm{O}+\mathrm{C} \rightarrow \mathrm{CO}_{2}+2 \mathrm{H}_{2}
\end{aligned}
$$

Therefore, it is suggested that the deposited carbon contains hydrogen but slightly.

Among the catalysts tested, basic materials such as dolomite and calcium oxide were found to be more effective for steam reforming than alumina and silica gel. Furthermore, it was found that catalytic activity was closely related to the rate of reaction between steam and carbon deposited in the absence of steam. The results suggest that steam reforming of $n$-hexane proceeds via highly reactive carbon deposited on the catalyst as an intermediate. Saito et al. ${ }^{13), 14)}$ have proposed the following reaction scheme for steam reforming of $n$-hexane on silica-supported nickel catalysts and they have concluded that the steam reforming proceeds mainly via the reaction between steam and the adsorbed hydrocarbon species on the catalyst (step I).

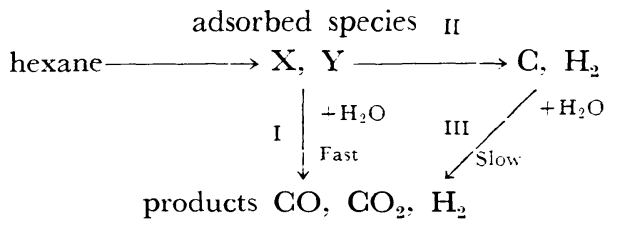

According to this reaction scheme, steam reforming on dolomite proceeds mainly through step II and step III.

Based on the assumption that deposited carbon is the intermediate of steam reforming, the reactivity of carbon deposited from various pure hydrocarbons was examined by use of the calcium oxide catalyst at $900{ }^{\circ} \mathrm{C}$. The results are shown in Figs. 10 and 11. In these figures, the rate of reaction between carbon and steam is plotted against the amount of carbon deposited. Cracking of various aromatic hydrocarbons and aliphatic hydrocarbons gave rise to deposited carbon of almost the same reactivity. Furthermore, the reactivity of carbon deposited

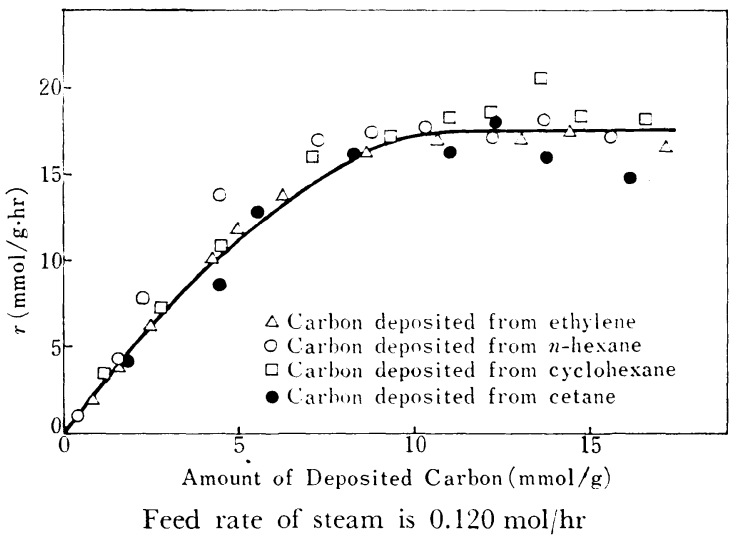

Fig. 10 Reactivity of Carbon with Steam Deposited from Hydrocarbons (mainly Aliphatic Hydrocarbons)

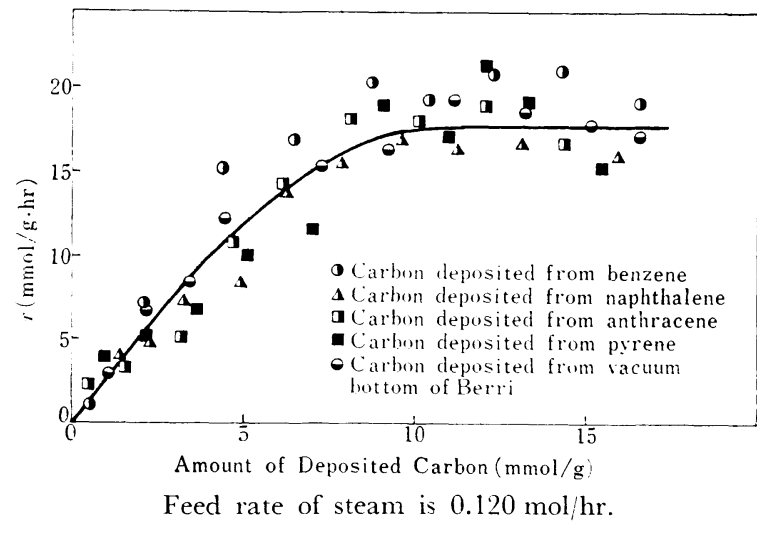

Fig. 11 Reactivity of Carbon with Steam Deposited from Aromatic Hydrocarbons and Heavy Oil

from vacuum bottoms of Berri was almost the same as that of the carbon deposited from various pure hydrocarbons as shown in Fig. 11. Accordingly, these results suggested that the nature of carbon deposited on calcium oxide was not affected by the species of hydrocarbons cracked.

\subsection{Desulfurization Capability of Dolomite}

Figure 12 shows the effect of residence time on $\mathrm{H}_{2} \mathrm{~S}$ yield in the product gas in gasification of topped bottoms of Arabian Medium. Here, $\mathrm{H}_{2} \mathrm{~S}$ yield was defined as the percent conversion of sulfur contained in the oil to hydrogen sulfide. Therefore, the smaller the yield of $\mathrm{H}_{2} \mathrm{~S}$ is the higher the ability of dolomite for desulfurization at the same gas yield. $\mathrm{H}_{2} \mathrm{~S}$ yield slightly decreased with increasing residence time up to about $0.4 \mathrm{sec}$. It seems that this is a rapid desulfurization reaction and is thermodynamically controlled. X-ray examinations of dolomite used gasification showed $\mathrm{CaO}$ in dolomite partly changed to $\mathrm{CaS}$, whereas $\mathrm{MgO}$ was unchanged. This result shows that $\mathrm{MgO}$ plays no part in fixing sulfur and only $\mathrm{CaO}$ is capable of accepting sulfur from hydrogen sulfide according to the reaction: $\mathrm{CaO}+\mathrm{H}_{2} \mathrm{~S} \rightleftharpoons \mathrm{CaS}+\mathrm{H}_{2} \mathrm{O}$, because the 


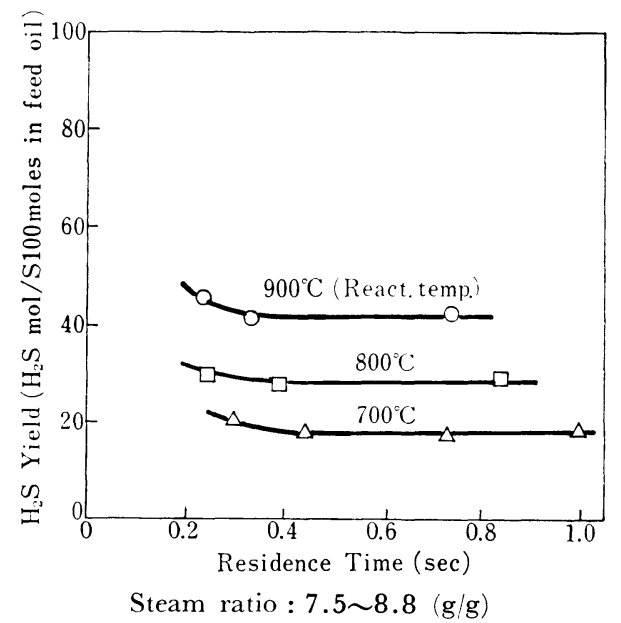

Fig. 12 Effect of Residence Time on $\mathrm{H}_{2} \mathrm{~S}$ Yield.

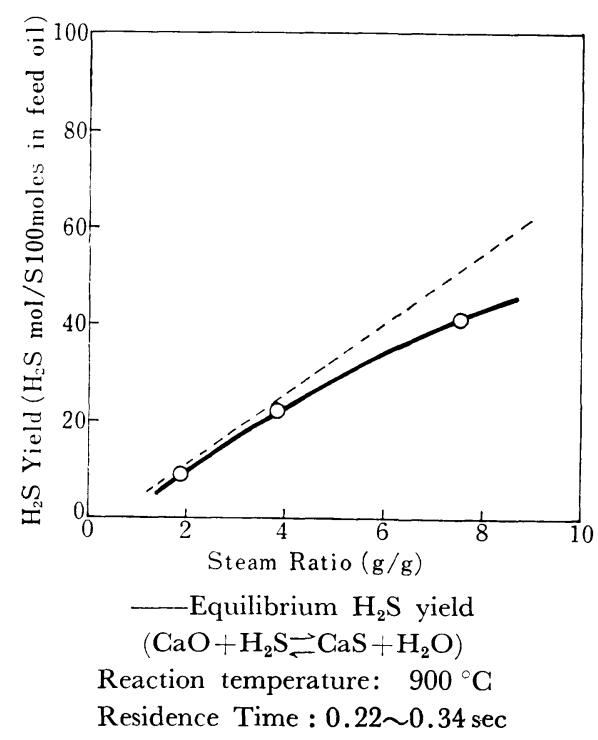

Fig. 13 Effect of Steam Ratio on $\mathrm{H}_{2} \mathrm{~S}$ Yield

equilibrium for conversion of $\mathrm{MgO}$ to $\mathrm{MgS}$ is unfavorable at all reaction conditions that are of interest to us as suggested by Squires et al. 18) Figure 13 shows the effect of steam ratio on desulfurization during gasification of topped bottom of Arabian Medium. In this figure, a dotted line represents the equilibrium yield of $\mathrm{H}_{2} \mathrm{~S}$ on the assumption that all the sulfur in the feed oil is converted to hydrogen sulfide, whose yield decreased with decrease in the steam ratio, always being very close to the equilibrium yield of $\mathrm{H}_{2} \mathrm{~S}$.

Percent desulfurization and $\mathrm{H}_{2} \mathrm{~S}$ concentration in the product gas obtained in gasification of various residual oils are plotted in Fig. 14 against the sulfur content in the feed oil. Percent desulfurization increased as the sulfur content increased, while the concentration of $\mathrm{H}_{2} \mathrm{~S}$ was almost unchanged. Table 4 shows the concentration of $\mathrm{H}_{2} \mathrm{~S}$ in the product gas and the ratio of partial pressure of steam to

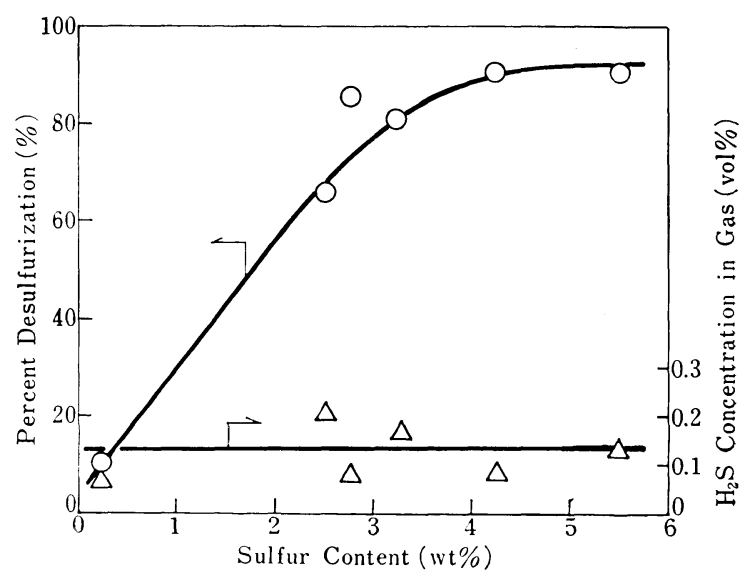

Reaction temperature : $900{ }^{\circ} \mathrm{G}$

Steam ratio : $2.8 \sim 3.0(\mathrm{~g} / \mathrm{g})$

Residence time : $0.4 \sim 0.5 \mathrm{sec}$

Fig. 14 Percent Desulfurization in Gasification of Various Oils

Table $4 \mathrm{H}_{2} \mathrm{~S}$ Concentration in Gaseous Products

\begin{tabular}{l|c|c|c}
\hline & $\begin{array}{c}\text { S Content } \\
(\text { wt } \%)\end{array}$ & $\begin{array}{c}\mathrm{H}_{2} \text { S Concentration } \\
\text { in Product Gas } \\
(\text { vol } \%)\end{array}$ & $\begin{array}{c}\mathrm{PH}_{2} \mathrm{O} / \\
\mathrm{PH}_{2} \mathrm{~S}\end{array}$ \\
\hline Mi. Top. & 0.14 & 0.04 & 2,656 \\
\hline Mi. Vac. & 0.28 & 0.07 & 1,326 \\
\hline Ir/H Top. & 2.55 & 0.21 & 446 \\
\hline A/L Top. & 2.81 & 0.09 & 642 \\
\hline Ber. Vac. & 3.26 & 0.17 & 429 \\
\hline A/L Vac. & 3.87 & 0.15 & 485 \\
\hline A/M Top. & 4.25 & 0.09 & 551 \\
\hline A/M Vac. & 5.50 & 0.14 & 649 \\
\hline
\end{tabular}

that of hydrogen sulfide $\left(\mathrm{P}_{\mathrm{H}_{2} \mathrm{O}} / \mathrm{P}_{\mathrm{H}_{2} \mathrm{~S}}\right)$ under the reaction conditions. Here, the partial pressure of steam was calculated from the amount of steam obtained by subtracting the amount of steam consumed in the formation of $\mathrm{CO}$ and $\mathrm{CO}_{2}$ from that of steam fed. The concentration of $\mathrm{H}_{2} \mathrm{~S}$ in the product gas was always about $0.1 \mathrm{vol} . \%$ regardless of the sulfur content in the feed oil. The $\mathrm{P}_{\mathrm{H}_{2} \mathrm{O}} /$ $\mathrm{P}_{\mathrm{H}_{2} \mathrm{~S}}$ ratio was almost constant except when residual oils of Minas of extremely low sulfur content were used. These results imply that $\mathrm{CaO}$ in dolomite reduces the concentration of $\mathrm{H}_{2} \mathrm{~S}$ in the product gas to its equilibrium value according to the reaction: $\mathrm{CaO}+\mathrm{H}_{2} \mathrm{~S} \rightleftharpoons \mathrm{CaS}+\mathrm{H}_{2} \mathrm{O}$.

Furthermore, it is predicted that $\mathrm{SO}_{2}$ concentration in the combustion off-gas becomes about 200 ppm when the fuel gas obtained in this study is burnt with excess air $(105 \%$ of stoichiometric amount required for combustion). This calculation is made 
on the assumption that hydrogen sulfide is completely converted into $\mathrm{SO}_{2}$ during combustion. This value of $\mathrm{SO}_{2}$ concentration is almost $2 / 3$ of the $\mathrm{SO}_{2}$ concentration resulted when Minas topped bottom is burnt with $105 \%$ of stoichiometric amount of air required for combustion.

\section{References}

1) Morita, Y., "Gasification of Heavy Oil" (1973) Fuel Society of Japan.

2) Hartman, M., Coughlin, R. W., Ind. Eng. Chem., Proc. Design and Develop., 13248 (1973).

3) Oil Gas J., 15, Sept., 94 (1969).

4) Craig, J. W. T., Johnes, G. L., Kowszun, Z., Moss, G., Taylor, J. H., Tisdall, D. E., PB 240632 (1974).

5) Keairns, D. L., Newby, R. A., O’Neill, E. P., Archer, D. H., Preprints, Symp. National Meeting, Am. Chem. Soc. Dir. Fuel Chem., 21, 91 (1976).

6) Yamamoto, K., Morita, Y., Kumada, K., Tanaka, M., J. Chem. Soc. Japan, (Ind. Chem. Soc.), 57, 682 (1954).

7) Morita, Y., J. Japan Petrol. Inst., 19, (3), 173 (1976).
8) Tomita, T., Kitagawa, M., Paper Presented at European Meeting of Chemical Engineering, Frankfurt (June, 1976).

9) Morita, Y., Izumi, K., Yamazaki, S., Ogawa, M., Kikuchi, E., J. Japan. Petrol Inst., 19, (4), 285 (1976).

10) Morita, Y., Osawa, N., Fukase, S., Yamazaki, S., Kikuchi, E., ibid., 20, (2), 142 (1977).

11) Kimura, T., Nishioka, K., Kikuchi, E., Morita, Y. J. Fuel Soc. Japan. in press.

12) Iijima, H., J. Japan Petrol. Inst., 5, (8), 559 (1962).

13) Saito, M., Tokuno, M., Morita, Y., Bull. Japan Petrol. Inst., 13, (1), 31 (1971).

14) Saito, M., Tokuno, M., Morita, Y., Kogyo Kagaku Zasshi (J. Chem. Soc. Japan, Ind. Chem. Sect.) 74, 693 (1971).

15) Yamamoto, K., Morita, Y., Tanaka, M., J. Fuel. Soc. Japan, 33, 593 (1954).

16) Morita, Y., "Sekiyu Kagaku Process I" (Processes of Petroleum Chemistry I), (1962) Asakura Shoten.

17) Morita, Y., "Shokubai Kagaku Koza 10, Shokubai Benran, 19 (1967).

18) Squires, A. M., Graff, R. A., Pell, M., Chem. Eng. Prog. Symp. Series, 67, 23 (1971).

要

旨

\section{焼成ドロマイト流動層による残油の水蒸気改質}

\section{森 田 義 郎*}

現在重質燃料のガス化はエネルギー資源の低公害有効利用法 として注目されている。この重質燃料のガス化プロセスは種々 提案1)されているが，ドロマイトや石灰を用いるプロセスはこ れらの物質が脱硫能力を有することから最も経済的でしかも環 境問題に対して有効なプロセスであり, 第 3 のガス化法として 最も期待されているものである。実際, 残油のガス化法として 石灰の流動層を用いるイギリスの Esso Research Center の開 発による CAFB 法4) や Westinghouse Research Laboratories によって開発されたドロマイトを用いる石炭の流動層によるガ ス化プロセス ${ }^{5}$ 等がある。さらにこれらの塩基性物質が高温ご の残油のガス化に対し活性な触媒であることも従来の研究6), 7) 15～17）から明らかにされている。この塩基性物質を触媒として ガス化プロセスに用いたものとして東洋エンジニアリングえ東 京瓦斯が開発した THR 法自や引三井造船と三井鉱山コークスで 開発した M-Gas 法がある。

しかし工業的な開発研究に比較してこれらの塩基性物質の触 媒作用や反応に関する基礎的研究は少ない。そこで本論文では 燃料ガス製造を目的として焼成ドロマイト流動装置を用い常圧 下での 8 種の異なる残油の水蒸気改質の研究を行った。

まず反応温度 (Table 2), 滯留時間 (Fig. 4), 水蒸気比 (Fig. 5) 等の諸条件を検討したがその最適条件は反応温度 90 $0^{\circ} \mathrm{C}$, 滯留時間 0.4 秒以上, 水蒸気比 2〜9 である。この条 件下では $90 \mathrm{wt} \%$ 以上のガス収率が得られた。

いずれの残油を原料油に用いてもほぼ 45\% の炭素が CO,

* 早稲田大学理工学部応用化学科 (160 東京都新宿区西大久 保 4-170)

\section{Keyword}

Desulfurization, Dolomite, Fluidized bed, Residual oils, Steam reforming
$\mathrm{CO}_{2}$ 㲹改質された (Fig. 6)。一方 $\mathrm{CH}_{4}, \mathrm{C}_{2} \mathrm{H}_{4}$ のような気体 炭化水素の収率は使用した残油によって変化した。そしてその 収率は残油の飽和成分の含有量と良い相関性を示した(Fig.6)。 この相関関係から気体炭化水素は主として残油中の飽和成分の 分解により生成することが示唆された。気体生成物 $(\mathrm{CO}+$ $\mathrm{CO}_{2}$, 炭化水素, $\left.\mathrm{H}_{2}, \mathrm{H}_{2} \mathrm{~S}\right)$ へ転化されない原料残油の割合と アスフォルテックス成分（アスフォルテン分+レジン分）の含 有量とが良い対応を示した (Fig. 7)。このことからアスフォル テックス成分のように重質な成分はガス化されにくいことが推 定された。

水蒸気改質により生成する水素の経時変化と析出炭素量のそ れ之が対応すること (Fig. 9), 析出炭素と水蒸気との反応速度 と水蒸気改質活性 $\left(\mathrm{CO}, \mathrm{CO}_{2}\right.$ の生成速度) とが良く対応するこ と(Table 3) から，ドロマイト上での水蒸気改質は中間体が活 性点上に析出した炭素であるという機構によって説明された。

ガス化中同時に硫化水素はドロマイト中の $\mathrm{CaO}$ によって除 去された。滯留時間の影響（Fig. 12）および水蒸気比の影響 (Fig. 13) の検討から脱硫反応速度は大で，次に示される反応 の熱力学的平衡近くで抑えられていることが示された $(\mathrm{CaO}+$ $\left.\mathrm{H}_{2} \mathrm{~S} \rightleftharpoons \mathrm{CaS}+\mathrm{H}_{2} \mathrm{O}\right)$ 。生成ガス中の $\mathrm{H}_{2} \mathrm{~S}$ 濃度は残油中の硫黄含 有量にほとんど無関係であり $900^{\circ} \mathrm{C}$ では約 $0.1 \mathrm{vol} \%$ であ った (Fig. 14, Table 4)。この結果からもドロマイトは生成 ガス中の $\mathrm{H}_{2} \mathrm{~S}$ 濃度を上式の平衡值まで減少させることが明ら かとなった。このガス化で得られた燃料ガスを燃焼に必要な化 学量論量の $105 \%$ の空気で燃焼すると, 燃焼廃ガス中の $\mathrm{SO}_{2}$ 濃度はほぼ $200 \mathrm{ppm}$ になる。この $\mathrm{SO}_{2}$ 濃度はうナスの常圧 残油を同じ空気量（燃焼に必要な化学量論量の 105\%) で燃焼 したとき生成する $\mathrm{SO}_{2}$ 濃度の $2 / 3$ である。 